\title{
Trademark Property and Human Rights*
}

\author{
BY SÁNDOR VIDA**
}

\begin{abstract}
The article reports on some judgments of the European Court of Human Rights applying the principles of the European Convention on Human Rights in respect of trademarks. The first group of cases relates to the freedom of expression (Art 10). In the cases Tokaji, Marlboro and McDonald's, the applicants referred to this principle to defend their actions related to the trademark. The second kind of cases relate to the protection of property (Protocol No. 1). In the case of Budweiser the European Court took the position in favor of applying this rule to a trademark application. The third group of cases relates to the right to a fair trial (Art. 6). According to reports on the Orient and McDonald's cases, the national courts committed important procedural faults. The conclusion of the author is that trademark rights can be protected by means of human rights only in exceptional circumstances.
\end{abstract}

Keywords: trademarks, freedom of expression, protection of property, fair trial

\section{INTRODUCTION}

It is commonplace that law satisfies social needs. Some social needs were recognised two thousand years ago, like protection of property, and others just about two-hundred years ago, like trademark protection, and there are some that were recognised just about half a century ago, these are e.g. human rights.

The codification of the latter was motivated by the horrors of the Nazi Holocaust during World War II as well as by the systematic slaughter of the Armenians during World War I, however this motivation can also be conceived as a need to defend citizens against the threat from their own nation State.

The first international document in this subject was the "Universal Declaration of Human Rights" proclaimed by the United Nations in 1948, which includes the right to life, the prohibition from torture and cruelty, inhuman treatment, etc.

Following some similar internationally issued documents, the Council of Europe taking over and completing the content of the Universal Declaration of Human Rights of the U.N. - initiated a Convention including the possibility of judicial sanctions, which was signed by the Member States at that time in Rome dated November 4, 1950. Hungary similarly to the other former socialist States signed the European Convention on Human Rights (hereinafter: Convention) after the regime change. ${ }^{1}$

Before we go ahead, in order to make a demarcation I consider it useful to note that in the following only the Convention and the decisions based on it made by the European Court of Human Rights (ECHR or Court) concerning trademarks will be discussed, nevertheless the courts of the USA, South-Africa, Australia ${ }^{2}$ and other countries also made some noteworthy human rights-related decisions in the trademark subject.

\footnotetext{
* The research work of this paper was sponsored by the Fritz-Thyssen Stiftung (Germany).

** LL.M Professor of Law. E-mail: vida@danubia.hu

1 Published in Hungary by Act XXXI of 1993.

2 Helfer (2011)
} 


\section{THE CONVENTION AND THE EUROPEAN COURT OF HUMAN RIGHTS}

Currently 47 European countries are parties to the Convention, including all Member States of the European Union.

With respect to the available reference material ${ }^{3}$ here I would like to note only that among the provisions of the Convention the following are especially noteworthy concerning trademarks:

- right to fair trial (Art. 6)

- freedom of expression (Art. 10)

- protection of property (Protocol I Art. 1).

Article 19 of the Convention provides for the establishment of the European Court of Human Rights and following this (Art. 20-51) for the organisation and procedure of this court. ${ }^{4}$ From the latter provisions, concerning our topic, noteworthy are the provisions of the Convention on individual complaints (Art. 34-45). As a result of allowing individual complaints and the court practice in connection with it, the ECHR became known widespread. Anyway, a complaint may be submitted only in cases where the applicant had previously exhausted all domestic remedies. Practically, this means the Supreme Court of the applicant's country.

In case the ECHR considers the individual complaint well-grounded then its decision states whether the State complained of had violated the specific article of the Convention, it often renders reimbursement of costs in favour of the complainant, moreover, in some cases compensation as well. The enforcement of the judgments is monitored by the Committee of Ministers of the Council of Europe.

At the same time it should be noted that the procedure of the ECHR is not a further procedural instance (fourth instance), which is emphasised by several decisions. ${ }^{5}$

The language of the decisions is English or French. All decisions can be found in the online database of the ECHR, however in paper form only a small percentage of them (the leading cases) is available, according to my estimation only about 5-10 percent of them.

\section{FREEDOM OF EXPRESSION}

Historically this provision ${ }^{6}$ of the Convention goes back to the legislation of the French Revolution. Freedom of the press became gradually accepted in 19 century Europe. It is

${ }^{3}$ Rainey (2014); Karpenstein (2012)

${ }^{4}$ Grád (2011); Leach (2011)

5 "It is not (the Court's) function to deal with errors of fact or law allegedly committed by a national court, unless and insofar as they may have infringed rights and freedoms protected by the Convention" (Garcia Ruiz v. Spain; Reports, 199-I, 589. para 28.).

${ }^{6}$ Text of Article 10 (in excerpts): "1. Everyone has the right to freedom of expression. This right shall include freedom to hold opinions and to receive and impart information and ideas without interference by public authority and regardless of frontiers [...]".

2. The exercise of these freedoms, since it carries with its duties and responsibilities, may be subject to such formalities, conditions, restrictions or penalties as are prescribed by law and are necessary in a democratic society, ... for the protection of health or morals, for the protection of the reputation or rights of others..." 
memorable that in Hungary Kossuth ${ }^{7}$ was imprisoned for four years for circumventing censorship. In connection with the criminal proceeding against Wesselényi and his company, in the Hungarian Parliament in Bratislava at that time Deák ${ }^{8}$ made several speeches for the protection of the freedom of the press. ${ }^{9}$

Nevertheless, the provisions of the Convention on the freedom of expression are not restricted to the freedom of the press, consequently neither are the decisions of the ECHR.

\subsection{The Tokaji case}

\subsubsection{Facts}

P. Új, a Hungarian journalist wrote a strongly critical article about the quality of the wine Tokaji distributed by Tokaj Kereskedőház in the daily paper Népszabadság dated January 2, 2008.

According to the article "[...] the product, a bottle of which is available for less than a thousand forint, represents the world's best wine region, the Hungarian National Pride and Treasure [...] and I could cry if I think of it. Not only because of the flavour, although that would be enough in itself [...] it is of bad quality, a mishmash of a load of garblings [...] and hundreds of thousands of Hungarians drink it with pride, even devotion, the shit, and we are fed with it (made to drink it) [...]"

The Tokaj Kereskedöház lodged a criminal complaint against the journalist, and the court of Budapest District II-III condemned Új for libel by suspending the penalty for a three-year probation. On appeal the case continued at the Metropolitan Court, which condemned the journalist for defamation. The second-instance judgment was confirmed by the Supreme Court.

Following this the journalist turned with his complaint to the ECHR.

\subsubsection{Judgment ${ }^{10}$}

The ECHR said, referring to its settled case law, that the use of vulgar phrases in itself was not decisive as they might serve merely stylistic purposes (judgment para 20), and that journalistic freedom also covered possible recourse to a degree of exaggeration, or even provocation (judgment para 21).

The Court accepted that in addition to public interest there was a competing interest in protecting the commercial success and viability of companies. The State therefore enjoys a margin of appreciation as to the means which risk harming its reputation (judgment para 22).

The Hungarian courts failed to have regard to the fact that press had a duty to impart information and ideas on matters of public interest and in doing so to have possible recourse to a degree of exaggeration or even provocation. The expression (shit) used is, regrettably, a commonly used one in regard of low-quality wine (judgment para 24).

\footnotetext{
7 Attorney at Law, journalist, Governor of Hungary during the war of independence from Austria (1848-1849).

${ }^{8}$ Member of Parliament, Minister of Justice (1848), one of the initiators of establishing the Austrian-Hungarian Monarchy (1867).

9 About both of them Koltay (2009) 55 and 59.

10 23954/10 Új v. Hungary 2011. 7. 19; Annual Report 2011, 102.
} 
The Hungarian courts did not examine the proportionality of criminal-law based interference with Article 10 of the Convention (judgment para 25) therefore Article 10 of the Convention was violated by them (judgment para 26).

With regard to the above the Court obliged the State of Hungary to pay EUR 3,580 as reimbursement of costs and expenses (judgment para 31 ).

\subsubsection{Remarks}

The journalist is surely not alone in his feelings to the geographical indication and trademark Tokaji. The wine Tokaji is justly famous all over the world. The French king Louis XIV declared it to be "the king of wines, the wine of kings" (Le roi des vins, le vin des rois), but the great German writer Goethe also wove the commemoration about the wine Tokaji into the Faust (in the Auerbach cellar, Leipzig).

It is a matter of fact, when giving their judgments, the domestic courts failed to have regard to Article 10 of the Convention as well as to the practice of the Court based thereon. Sajó ${ }^{11}$ states correctly that "in the Hungarian practice, with regard to issues [...] of public interest, the interest of freedom of expression did not receive due attention." Sajó ${ }^{12}$ is also right in saying - of course independently from this case - that the "Hungarian courts pay little attention to the impacts made on the freedom of expression if in a discussed case the interest of persons is at stake who are in close connection with the government." Further, in my view, the statement of Polgári, ${ }^{13}$ which is based on experience, seems to be proven that there is almost no trace of the implementation of the case law regarding Article 10 of the Convention in Hungarian case law.

In contrast, the Court of Justice $\mathrm{EU}^{14}$ (Luxembourg) examined the questions of human rights in connection with the European settlement of the use of the geographical indication Tokaji when in a procedure in Italy the Italian administrative court (Lazio) referred the case to the Court of Justice EU. Among others the Court was asked to answer the question whether the agreement of 1993 between the European Community and Hungary violated the Convention, since in consequence of it the wine-growers of the Friul wine region could not continue using the indications "Tocai", "Tocai friuliano", "Tocai italic" after the transitional period of more than 10 years had lapsed. The answer of the Court of Justice EU was "not". In the reasoning it referred to Article 1 of the Protocol I of the Convention, according to which the public interest of a State may regulate the use of property right, alternatively the practice of the ECHR, according to which the limitation of property is legal if the aim is legitimate and the applied means are not disproportionate.

Finally, after the procedure had ended, it also turned out that the journalist was also right in fact: the Tokaj Kereskedöház (presumably the new management) admitted that the wines had been adulterated for 25 years. ${ }^{15}$ Therefore the Tokaj Kereskedőház recalled a significant amount of its wine from the market, which resulted in a shortage of supply and price change for almost a year.

11 Sajó (2005) 156.

12 Sajó (2005) 182.

13 Polgári (2008) 117.

14 C-374/03 para. 118-134.

15 Metropol 5.5.2014, 6; Népszabadság 4.10.2014, 9. 
The judgment is in conformity with the settled case law of the ECHR, we could even say with its philosophy, according to which the function of the press is to remain vigilant with regard to the functioning of the society, to serve as a public watchdog.

\subsection{The Marlboro case}

\subsubsection{Facts}

In No. 6 of 2002 of the French Entrevue magazine an article was published about the incredible income of some sportsmen, particularly pointing out Schumacher and Zidane. In one of the pictures Schumacher raises a Marlboro cigarette package, in another the same trademark can be seen on his safety helmet. Based on the complaint filed by the French Committee Against Smoking (C.N.C.T.) at first instance the T.G.I. Paris fined jointly the publisher and the chief editor of the magazine by EUR 30,000 in a procedure for prohibited advertising. The Court of Appeal added a further EUR 10,000 damages to it and the Cour de Cassation refused the request for appeal.

The persons convicted filed a complaint to the ECHR for violation of Article 10 of the Convention.

\subsubsection{Judgment ${ }^{16}$}

The claimants referred to the fact that the contested photographs were not tobacco advertisements, but true pictures about Schumacher as the photo was taken of him after his triumph (judgment para 40).

According to the statement of the Court, although the convictions are considered as an interference into the freedom of expression, in this case it occurred in the interests of public health (judgment para 43).

Protection of public health, for which the laws of both the complained State and the European Union provide, can overwrite economic interests, or in a given case even such basic rights like the right to freedom of expression (judgment para 46).

The Court states that the national court condemned the claimants for surreptitious advertising (publicité indirecte) of tobacco products (judgment para 48).

"The contested photographs do not record a given moment of time but rather a stagelike scene behind which the sponsoring company of the sporting event stands [...] The claimants could have tarnished the contested logo without risking that the information in the article was injured" (judgment para 49).

Considering the aims of health protection, namely the prevention of smoking, the measures taken against the freedom of expression are justified and proportionate to these legal objectives (judgment para 52).

Finally, the Court remarks that pursuant to the French case law, photographs published on sporting events after hours or days do not fall under the exclusive exemption which the live sports media enjoys in case of indirect advertising - as it was also mentioned in the judgment of the Cour de Cassation (judgment para 64).

Taking all the above into consideration the ECHR stated that Article 10 of the Convention had not been violated.

16 26953/05, 5.3.2009. Société de Conception de Presse et d'Edition et Ponson v. France. 


\subsubsection{Remarks}

The judgment refers not only to the French legal provisions and practice (judgment para 2021) but also to the Community law (judgment para 22-23) as well as the documents of the Council of Europe (judgment para 24), the World Bank (judgment para 26), as well as the framework contract of the World Health Organisation (judgment para 27), i.e. a wide range of provisions on the prohibition of advertising tobacco products.

Definitely convincing is the provision taken over resp. cited from the judgment of the Cour de Cassation making difference between press and TV advertising. While in live sports media advertising of tobacco products is allowed, in the press it is prohibited. In my view the obvious reason for the different provisions is that while in case of broadcasting sports events the viewers pay attention to the event itself and so the advertisement has a secondary role and when the broadcasting stops, it will be forgotten to some extent, but press advertising (especially in case of magazines) is persistent and by handing over press products to other readers it can make its effect more widely, particularly in case of an interesting article.

The reference literature ${ }^{17}$ mentions this judgment as an example for a measure in favor of health protection which also extends to tobacco advertising. Leach ${ }^{18}$ writes a brief summary on the judgment and refers to another judgment of the ECHR (similarly in the subject of advertising a tobacco trademark), in which the court refused the complaint as well.

\subsection{The McDonald's (I) case $^{19}$}

\subsubsection{Facts}

London Greenpeace made an anti-McDonald's campaign: they produced and distributed a six page leaflet with the title "What's wrong with McDonald's", each page of which comprised the McDonald's logo. The highly critical leaflet dealt with the following issues: "What's the connection between McDonald's and starvation in the Third World?", "Why is it wrong for McDonald's to destroy rainforests?", "What's so unhealthy about McDonald's food?", "How do McDonald's deliberately exploit children?", "In what way are McDonald's responsible for torture and murder?", "What is it like working for McDonald's?"

Since London Greenpeace was not an incorporated body, McDonald's hired private investigators to find out who was responsible for the leaflet. Subsequently, the US and UK McDonald's started a court procedure against five identified activists for libel. Three of the defendants apologised for the leaflet and McDonald's withdrew proceeding against them so the defamation proceeding continued only against Helen Steel and David Morris. The former of them worked occasionally and the other was unemployed being responsible for the day-to-day care of his four year-old son as a single parent. Both of them were dependent on income support.

The High Court found that some statements of the leaflet were true, namely that

- McDonald's used children to pressurise their parents

17 Karpenstein (2012) 49.

18 Leach (2011) 6.502.

19 The number "I" indicates that only the part of the case will be discussed here which concerns freedom of expression, later I return to the case in connection with Article 6 of the Convention. 
- McDonald's was culpably responsible for cruel practices in the rearing and slaughter of some of the animals which are used to produce their food

- McDonald's (in the UK) pays its workers lower wages than customary and thereby it helps to depress professional wages.

However, the High Court found the other allegations and opinions in the leaflet untrue and therefore it obliged David Morris to pay each of the two plaintiffs, McDonald's USA and McDonald's UK GBP 30,000 (altogether GBP 60,000) and Helen Steel to pay each of them GBP 27,500 (altogether GBP 55,000) damages.

The appeal filed by the defendants was rejected, the Court of Appeal only reduced the sum of the damages payable to the half and for the rest it said that there was a public interest that information about the activities of companies was made available for the public and the duty to publish this also applied to the accused campaigners, nevertheless the criterion of immunity was that the information should be published in measured tone and based on reputable sources. In the instant case the allegations of the leaflet did not seem to meet these requirements. The judgment of second instance refused further appeal.

Despite this fact the defendants filed appeal to the House of Lords, which also refused the applicants' leave to appeal.

After this the defendants turned to the ECHR for violation of Article 6 (right to a fair trial) and Article 10 (freedom of expression) of the Convention.

\subsubsection{Judgment $t^{20}$}

Complainants did not choose to commence defamation proceedings but to protect their freedom of expression (judgment para 63).

The Court had to weigh a number of factors in order to establish whether the judgments of the British courts had been proportionate to the objected actions. First, the fact is to be acknowledged - says the judgment - that the leaflet in question contained very serious allegations on topics of general concern, such as abusive farming practices, deforestation, exploitation of parents by children advertising, sale of unhealthy food. The court has long held that "political expression", including expression on matters of public interest and concern, requires a high level of protection under Article 10 (judgment para 88).

Contrary to the the British government, the Court was of the view that in a democratic society even small and informal campaign groups, such as London Greenpeace, must be able to carry on their activities effectively, namely to contribute to the public debate by disseminating information and ideas on matters of general public interest such as health and the environment (judgment para 89).

The Court has held on many occasions that even the press must not overstep certain bounds and the same principle had to be applied to others who engaged in public debate. Nonetheless, journalists are allowed to recourse to a degree of exaggeration, or even provocation. The same applies for a campaigning leaflet, and even it is expected from it (judgment para 90).

With regard to the above the judgment concludes that the United Kingdom violated Article 10 of the Convention.

20 68416/01, 15. 2. 2005, Steel and Morris v. United Kingdom, Reports 2005-II, 46. 


\subsubsection{Remarks}

In a democratic society criticism is of fundamental importance. ${ }^{21}$ Independently from the judgment presented here, Rahmatian ${ }^{22}$ says that in proceedings started for criticism (or trademark parody) the national courts are quite careful regarding the human rights aspect of cases.

To my knowledge this was the first case when the ECHR considered the freedom of publishing critical and hard-hitting opinions enjoyed by journalists admissible in case of a campaign group of private persons as well. This sentence of the judgment (judgment para 90) is cited not only by Hudson ${ }^{23}$ and Grabenwarter ${ }^{24}$ but also by J. P. Costa, ${ }^{25}$ the president of the ECHR at that time, in his report held in Helsinki. It is also mentioned by several commentators, e.g. by Leach ${ }^{26}$ or Jacobs, White and Ovey. ${ }^{27}$

None of the courts can afford to make unilateral judgments, and the ECHR is not an exception to that either. This judgment also starts with reference to "the protection of the reputation or rights of others" (judgment para 86) and then multinational concerns are specified (judgment para 94), i.e. McDonald's.

McDonald's is presumably the greatest fast-food chain of the world: they operate almost 35.000 restaurants in 118 countries, the number of their employees is about 440.000 . As of the 1980s the companies of the holding have been experiencing several similar attacks (also in the UK), the American holding wanted to make a deterrent example of the activists in order to protect their name and trademark.

The British courts proceeded with indisputable attention, but yet they did not pay proper attention to the freedom of expression i.e. to Article 10 of the Convention.

\subsection{Intermediary evaluation}

Freedom of expression and trademark protection? It is clear that trademarks had just the leading position in the above cases and that there are no trademark law issues in the judgments. Nevertheless, these still affect trademark property in the following areas:

Protection of the journalist, who protests against dilution of the trademark with drastic words (Tokaji).

Protection of the trademark owner's interest, when he struggles for maintenance of his trademark's reputation (McDonald's).

A negative example, when a well-known trademark (Marlboro) is subject to surreptitious advertising and in the meantime also a third person (owner of the magazine) wants to exploit the trademark's good reputation.

21 Grabenwarter (2014) 46.

22 Rahmatian (2008) 350. Examples from the French court practice: Stop Esso, Camel with cigarette in its mouth.

23 Hudson (2005) 301: “[... strong public interest in enabling such groups and individuals outside the mainstream $[\ldots]$ ".

24 Grabenwarter (2014) 30.

25 Council of Europe, European Court of Human Rights, 5.6.2008.

26 Leach (2011) 6.466.

27 Rainey (2014) 444. 


\section{PROTECTION OF PROPERTY}

Protocol I Article 1 of the Convention ${ }^{28}$ provides for the protection of property. Property is one of the oldest legal concepts developed already by Roman Law. The Convention uses the expression "possession". This means not only tangible assets but also intellectual property and the ECHR gave several judgments in the areas of copyright, ${ }^{29}$ patent and trademark property. Of the judgments in the latter subject I will discuss the best-known one in the following.

\subsection{The Budweiser case $^{30}$}

\subsubsection{The Facts}

The Anheuser Busch, Inc. has used the trademark Budweiser in the USA since 1876 and after about a hundred years they broke into the European market and filed trademark applications in several countries, among others in Portugal in 1981.

Here they were confronted with the much older Czech Budweiser sign, which has been registered in the international registry of appellations of origin since 1968.

Despite this fact the Portugal Institute for Industrial Property recorded the Budweiser trademark of the American company which was attacked by the owner of the Czech appellation of origin Budweiser. The latter based his claim on the Portuguese-Czechoslovak Bilateral Agreement on the Protection of Indications of Source, Appellations of Origin signed in 1986. The claim was successful, the Portuguese courts, including the Supreme Court ordered cancellation of the American company's trademark based on the Bilateral Agreement.

Against this judgment the company Anheuser Busch turned to the ECHR.

\subsubsection{Judgment of the Chamber}

According to the first instance proceeding at the Chamber, Portugal did not violate Protocol I Article 1 of the Convention since it can be applied only to a person's existing possessions. Therefore a prospective right not yet existing, i.e. an application for registration of a trademark cannot be regarded as possession. The complainant cannot be sure of being the owner of the trademark in question until after its final registration. In the light of this, on May 7, 1987, at the time of signing the Bilateral Agreement the complainant had no possession which falls within the scope of the Convention. The applicant company filed appeal against the judgment to the Grand Chamber.

\subsubsection{Judgment of the Grand Chamber ${ }^{31}$}

The Grand Chamber consisting of 17 judges also found that Portugal had not violated Protocol I Article 1 of the Convention.

Here I will discuss only those parts of the judgment which contain trademark issues.

28 Text of Protocol I Article 1: "Every natural or legal person is entitled to the peaceful enjoyment of his possessions. No one shall be deprived of his possessions except in the public interest and subject to the conditions provided for by law and be the general principles of international law $[\ldots]$ '..

\footnotetext{
29 Gyenge (2010)

30 The case is discussed in detail by Vida (2014) 87.

31 7830049/01, 11.1.2007. Anheuser Busch v. Portugal.
} 
a) Trademark application

The legal position of the applicant for registration of a trademark has certain financial implications, including those attendant on an assignment (possibly for consideration), or a licence, and those arising out of the priority of an application for registration afforded over subsequent applications. Nevertheless, the applicant cannot be sure of being the owner of the trademark in question until after final registration and then only on condition that no objection was raised by a third party, as the relevant legislation permitted. In other words, the applicant company had a conditional right, which was extinguished retrospectively for failure to satisfy the condition, namely that it did not infringe third-party's rights (judgment para 74).

It should be considered whether the applicant company became the owner of the Budweiser mark on June 20, 1995, when the Portugal Institute for Industrial Property issued a registration certificate for them, however this circumstance is of secondary importance. Namely the issue of the certificate to the applicant company was in breach of the provisions of Article 7 of the Code of Industrial Property. ${ }^{32}$ Thus, these circumstances cannot alter the nature of the possession to which the applicant company lays claim or the reality of its overall legal position for the purposes of Protocol I Article 1 (judgment para 75).

With this in mind the Court takes due note of the bundle of rights and financial interests that arise upon an application for registration of a trademark. The Grand Chamber states that such applications may give rise to a variety of legal transactions, such as sale or licence agreement which possess or are capable of possessing a substantial financial value. With regard to the submission of the Portuguese government that deals in respect of applications for the registration of a mark are of negligible or symbolic value the Court notes that in a market economy, value depends on a number of factors and it is impossible to assert that the assignment of an application for the registration of a trademark will have no financial value. In the instant case, as the applicant company pointed out, the mark in question possessed a definite financial value on account of its international renown (judgment para 76).

These elements taken as a whole suggest that the applicant company's legal position as an applicant for the registration of a trademark came within Protocol I Article 1, as it gave rise to interests of a proprietary nature. It is true that the registration of the mark - and the greater protection it afforded - would only become final if the mark did not infringe legitimate third-party rights. This means, the rights attached to an application for registration were conditional. Nevertheless, when it filed its application for registration, the applicant company was entitled to expect that it would be examined under the applicable legislation if it satisfied the other relevant substantive and procedural conditions. The applicant company therefore owned a set of proprietary rights that were recognized under Portuguese law. Although these could be revoked under certain conditions, the former fact suffices to make Protocol I Article 1 applicable in the instant case further to that the Court examines whether the applicant company could claim to have a legitimate expectation (judgment para 78).

${ }^{32}$ According to Section 7 the certificate of registration must be published after the decision becomes final. In case an appeal was filed the prescribed action is to be performed only after the court's decision becomes final. 
b) Whether there has been an interference

According to the applicant company the Lisbon Supreme Court's judgment of January 23, 2001 was an interference as it attached a greater weight to the Bilateral Agreement of 1986 than to the chronologically earlier application for registration of the Budweiser mark. In their view that judgment had effectively deprived the applicant company of their right of property of the mark in circumstances which, in its submission, infringed the relevant international instruments and Protocol I Article 1 for failure to comply with the priority rule. Had the Bilateral Agreement not been applied, the applicant company's application for registration would necessarily have been accepted, since it satisfied all the other applicable statutory conditions (judgment para 80).

In the light of the above, the question before the Court is whether the decision to apply the provisions of the Bilateral Agreement of 1986 to an application for registration filed in 1981 could amount to interference with the applicant company's right to the peaceful enjoyment of its possessions (judgment para 81).

In the instant case it was not established that the applicant company had right of priority in respect of the Budweiser mark when the Bilateral Agreement, which was alleged to have been applied retrospectively, came into force. In this connection, the Court points out that the only effective registrations in existence when the Bilateral Agreement took effect on March 7, 1987 were the appellations of origin that had been registered in Budejovickỳ Budvar's name under the Lisbon Agreement. While it is true that these registrations were subsequently canceled, the Court cannot examine what consequences the cancellation of the registration had on the right of priority attached to the mark (judgment para 84).

These are questions whose rightful place was before the domestic courts. The Portuguese Supreme Court decided in its judgment of January 23, 2001 to reject the applicant company's argument based on an alleged violation of the priority rule. In the absence of any arbitrariness or manifest unreasonableness, the Court cannot call into question the findings of the Supreme Court on this point (judgment para 85).

In the light of the foregoing, the Court therefore concludes that the Portuguese Supreme Court's judgment deciding the legal dispute did not constitute interference with the applicant company's right to the peaceful enjoyment of its possessions. There has, therefore, been no violation of Protocol I Article 1 (judgment para 87).

\subsubsection{Remarks}

Beiter ${ }^{33}$ from South-Africa states of the judgment that it has three main messages. These are a) the connection between the trademark and the appellation of origin, b) the application of Protocol I for intellectual property, c) the resolution of the given case.

About the connection between the trademark and the appellation of origin he explains that the view appearing in the judgment that the application for registration of a trademark is overridden by the Bilateral Agreement, is in conformity with the decision ${ }^{34}$ of the Dispute Settlement Body of the World Trade Organization (WTO) as well, which in the cited case, subject of which was also the collision between an appellation of origin and a trademark, decided in favor of the former one.

33 Beiter (2008) 724.

34 WT/DS147/R, decision of 15. 3. 2005. 
He says that it is questionable whether trademarks should be granted protection under human rights law. In his view it can be contested whether in addition to scientific, literary or artistic property, human rights protection can be extended to trademarks as well.

In his view, resulting from the decision of the Portuguese Supreme Court, there had been an unlawful expropriation of property and the ECHR should rather have analysed this issue.

It would be inappropriate to consider Helfer's ${ }^{35}$ extensive writing as a commentary, which reviews the ECHR judgments on the subject of intellectual property, but he puts the emphasis on the judgment made in the Budweiser case. Although he notes as a preliminary point that the above discussed proceeding can just be regarded as a little skirmish in the extended litigation war, which lead to about fifty court procedures between the American and Czech companies in the past quarter of the century; despite this evaluation he analyses the case quite thoroughly.

He examines in particular how the Court coped with the question of State interference (i.e. with the judgments of the Portuguese courts). Concerning this issue he is of the opinion that due to the prohibition to apply a legal provision with retroactive effect, the request of the American complainant was well-grounded. The situation is different in case of the review of the domestic court judgments. In this respect the Court always made a review only in very limited circumstances (in absence of any arbitrariness or manifest unreasonableness).

Following this, based on the lessons learnt from the Budweiser judgment, however cutting oneself adrift from it, he makes a prognosis. He shares namely his thoughts thereon, what kind of judgments concerning intellectual property cases can be expected in Strasbourg. In this respect he sets up three paradigms: a) the rule of law paradigm; b) the enforcement paradigm; c) the balancing paradigm.

a) About the rule of law paradigm he says that it can be stated both from the judgment rendered in the Budweiser case and from the case law referred to therein that in review of the decisions of domestic courts and authorities the ECHR limits his role to cases which can be considered as arbitrary or unreasonable, and this also applies to judgments which cover the subject of intellectual property. To support his prognosis, he mentions two examples: the Balani vs. Spain case, in which the Spanish Supreme Court disregarded the priority of the trademark owner and on request of the competitor the trademark was canceled. The other is: the unreasonable length of the procedure, e.g. in a patent infringement case in Slovenia no judgment was passed for 11 years.

b) He interprets the enforcement paradigm as the "positive obligations" of the States, namely that they are obliged to protect private property. In respect of intellectual property this means that a fresh set of complaints should be generated, or with the wording of TRIPS "fair and equitable" procedures.

c) In his view, the Court's adoption of an intellectual property balancing paradigm would have negative consequences for innovation and creative law and policy. He believes that the judgment in the Budweiser case suggests that retroactive laws that deprive intellectual property owners of an existing asset, may violate Protocol I Article 1. The retroactive legal actions of the States can namely upset investment expectations calculated based on the preceding legal situation. Therefore, such measures should be examined in light of article 13 of the TRIPS (limitations and exceptions). 
In his comprehensive but more concise study the German Sebastian ${ }^{36}$ reports on more human rights judgments rendered in intellectual property subject and considers that among these the Budweiser, i.e. Anheuser Busch case is the most important.

An important message of the judgment is - he believes - that the main function of the ECHR is the control of the States' measures, among others the control of their court ruling, however in this case its right is limited to the control of arbitrary and unreasonable judgments.

From the rulings of the judgments considered to be important by him he highlights the following:

- the applied legal interpretation is autonomous, i.e. it is based on the text of the Convention (para 62, 63),

- the provisions of the Convention on the protection of property can also be extended to assets, pursuant to intellectual property (para 62, 65, 69, 71, 72, 75, 78, 79, 83),

- a trademark application can be granted protection based on the Convention (para 78),

- to the latter it is sufficient if the trademark application can be the subject of the business (para 76).

Besides the two commentaries disclosed here all Handbooks on the Convention mention this judgment in at least one sentence when discussing Protocol I Article 1.

In respect of trademark law, I believe, at first the statements of the judgment in connection with the legal assessment of the trademark application (judgment para 74, 78) must be mentioned.

In this regard the consistent standpoint of both the proceeding Chamber and Grand Chamber is that a trademark application creates a pending legal situation. This situation can be changed into a defendable legal situation on two conditions: firstly, if following the formal and substantive examination the authority for industrial property considers the sign to be capable of protection, secondly, if no third person files an objection against it based on his earlier rights.

The question is, what the situation would be if the application was not filed for a reputed mark but for a plain trademark application? In this respect presumably the circumstances of the case (creativity, authenticity) may be decisive.

\section{2. Intermediary evaluation}

Property is the only right of economical value which is protected by the Convention besides political and civil rights. Protocol I Article 1 unequivocally covers intellectual property, and so trademark property, too. Among trademark property cases the Budweiser case is the most significant. ${ }^{37}$

Concerning trademarks, also the question arises what the situation with goodwill is, namely with the goodwill of a trademark. Can the goodwill of a trademark be separated from the trademark itself, or not? More specifically, can the trademark be separated from its customers, ${ }^{38}$ or not?

36 Sebastian (2013) 524.

37 For example the complaint for interference into property right (including trademarks) is considered to be inappropriate as by refusing the approval of the assignment the same becomes redundant also in respect of trademarks.

38 About loyal customers being a goodwill cf. Karpenstein (2012) 22. 
In my view, the goodwill of a trademark is in close connection with the trademark itself, that it can hardly be separated from it. Nevertheless, in case of a state interference (seizure, expropriation, etc.), the goodwill and the trademark (in itself) are subjects to a separate evaluation.

\section{RIGHT TO FAIR TRIAL}

From practical, legal and symbolic aspects Article 6 of the Convention ${ }^{39}$ is of fundamental significance. This provision is influenced by the principle of "due process of law" in AngloAmerican law. ${ }^{40}$ In the reference literature the dominant opinion appears that this is the most important provision of the Convention. This provision reflects the European constitutional principle of the rule of law.

At the same time, it was pleasing for me that I could reveal solely one judgment declaring a violation of Article 6 of the Convention in the trademark subject i.e. concerning human rights. Although in the other case the leading role has a trademark, the legal issue does not concern trademark law.

\subsection{The Orient case}

\subsubsection{Facts}

The Japanese company Orient Watch Co., whose mark had been protected since 1950, filed a request for cancellation against the trademark Orient H.W. Balani Malaga in Spain. Both parties use their trademark for watches. The Madrid First-Instance Court refused the request for cancellation action among others on the reason that the owner of the contested trademark had a prior mark Creations Orient, which had been registered in 1934.

The Japanese company appealed to the Supreme Court, which held that the contested trademark was not valid (not "established"). However, it made no reference to the earlier mark Creations Orient in its judgment.

The owner of the Spanish trademark which was removed from the register filed a complaint to the ECHR for violation of Article 6 of the Convention.

\subsubsection{Judgment ${ }^{41}$}

Article 6 of the Convention obliges the courts to give reasons to their judgments. However, this cannot be understood as requiring a detailed answer to every submission filed by the parties. The question whether a court has failed to fulfill the obligation to state reasons, deriving from Article 6 of the Convention, can only be determined in the light of the circumstances of the case (judgment para 27).

39 Text of Article 6: " 1 . In the determination of his civil rights and obligations or of any criminal charge against him, everyone is entitled to a fair and public hearing within a reasonable time by an independent and impartial tribunal established by law. Judgment shall be pronounced publicly but the press and public may be excluded from all or part of the trial in the interests of morals, public order or national security in a democratic society, where the interests of juveniles or the protection of the private life of the parties so require, or to the extent strictly necessary in the opinion of the court in special circumstances where publicity would prejudice the interests of justice [...]".

40 Grabenwarter (2014) 6.1.

41 18064/91, 9. 12. 1994. Hiro Balani v. Spain. 
In the instant case the applicant contested the action for removal of her trademark from the register, inter alia, on the basis that the Spanish Supreme Court ignored her submission based on the priority of another mark that she owned. This submission was sufficiently proved in the first-instance court proceeding. The Supreme Court, which gave a different judgment, was bound to review all the submissions made during the proceedings, or at least the subject of argument. It is not the task of the Court to examine whether the submission based on the priority ratione temporis of Creations Orient was well-grounded; it falls to the national courts to determine questions of that nature.

It is necessary to establish whether the silence of the Supreme Court on this question can be reasonably construed as an implied rejection, i.e. whether the prior trademark Creations Orient has priority over the company mark Orient Watch Co. This is a matter of law and logic. Further, it should also be established whether the company mark Orient Watch Co. collides with the company mark Creations Orient. The first question requires a specific and express reply. In the absence of such a reply, it is impossible to ascertain whether the Spanish Supreme Court simply neglected to deal with the submission based on the prior right or whether it intended to dismiss it and, if so, what its reasons were for so deciding.

Based on the above the ECHR stated that the Spanish Supreme Court had violated Article 6 of the Convention (judgment para 28) and obliged the State of Spain to reimburse the costs and expenses of the procedure for the applicant (judgment para 31).

\subsubsection{Remarks}

It is difficult to disagree with the judgment of the ECHR. In essence the withdrawal of a right existing for 25 years was at stake before the national court, which was even supported by an older right (from 1934).

It cannot be established from the judgment of the ECHR which aspects the Spanish Supreme Court took into consideration when it stated the invalidity of the trademark Orient H.W. Balani Malaga. In accordance with its settled case law the ECHR did not examine the merit of the case, and it was satisfied with establishing the fact that the judgment of the Spanish Supreme Court was incomplete.

Also in accordance with its settled case law the ECHR said finally that it is the duty of the national court to decide on the merit of the case (like the Court of Justice EU in the reference cases). The basis of this consistent case law is that Article 6 of the Convention applies to the proceeding and not to its outcome or result.

It would be interesting to know the subsequent case-history: how the Spanish Supreme Court decided. Was the result an in integrum restitution of the mark Orient?

\subsection{The McDonald's (II) case}

\subsubsection{Facts}

This case has already been discussed from the aspect of substantive law (freedom of expression), but I believe it is more interesting from the aspect of procedural law.

Before the trial started there were 28 pre-trial hearings, some lasting up to five days. The trial lasted for 313 days (for two and a half years), this was the longest trial ever in the English legal history (civil or criminal). The transcripts of the trial occupied 20.000 pages, the documentary evidence ran to about 40.000 pages and 130 witnesses gave oral evidence. The first-instance judgment consists of 762 pages.

In the first-instance case the defendants requested the court to grant legal aid. But defamation was expressly excluded from legal aid regime by the effective legal act (Legal 
Aids Act 1988). At the same time the restaurant chain McDonald's was represented by solicitors being experts in defamation cases. At some hearings the defendants were assisted by solicitors acting pro bono, however for the bulk of the trial they acted alone.

In addition, the defendants were unable to pay for the transcripts of the proceedings (which would have cost GBP 375 per day), and finally after some weeks could buy the transcripts at reduced costs (for GBP 25 per day), so they purchased these from donations. Therefore, in the procedure they referred to the fact that they could not prepare with questions to the witnesses and experts.

In their appeal the defendants also referred to the fact that given the complicated procedure the plaintiffs were financially strong while they were representing themselves under difficult circumstances and this situation caused an abuse of the judiciary service. The Court of Appeal rejected these submissions. It stated that the judge of the first-instance procedure had been impartial and objective and the defendants had conducted their case forcefully and with persistence.

Since the defendants did not agree with these statements, they filed their complaint based also on violation of Article 6 of the Convention.

\subsubsection{Judgment ${ }^{42}$}

The right to fair trial means among others that the parties enjoy equality of arms before the court (judgment para 59).

The question whether the provision of legal aid is necessary for a fair hearing must be determined on the basis of the particular facts and circumstances of each case and will depend, inter alia, upon the complexity of the relevant law and procedure, the importance of what is at stake for the applicant in the proceedings, the applicant's capacity to represent him or herself effectively (judgment para 61).

The defamation procedure was not initiated by the claimants. Moreover, as a consequence of their financial situation they failed to understand and reply to all the questions arisen in the procedure (judgment para 63).

Besides the complexity of the case the length of the judgments of the courts was extraordinary, too. In addition, a number of experts took part in the procedure dealing with questions such as nutrition, degenerative disease and food safety. The length of the firstand second-instance judgments exceed 1.100 pages and the facts were also complicated (judgment para 65).

Nor were the legal issues simple, including the meanings to be attributed to the words of the leaflet, the question whether the applicants were responsible for its publication, the distinction between fact and comment, the admissibility of evidence (judgment para 66).

Despite the fact that they received some legal help from time to time, e.g. their initial pleadings were legally drafted and they were assisted by barristers and solicitors on some hearings, for the bulk of the proceedings they acted alone (judgment para 68).

The denial of legal aid contributed to an unacceptable inequality of arms and therefore Section 1 of Article 6 of the Convention was violated (judgment para 72).

With respect to the above circumstances the judgment condemned Great-Britain to pay EUR 20.000 to the first applicant and EUR 15.000 for the second applicant as compensation for non-pecuniary damage, and further EUR 47.311 altogether for both of them as reimbursement of costs and expenses.

42 68416/01 15.2.2005., Steel and Morris v. United Kingdom; Reports 2005-II. 


\subsubsection{Remarks}

The contrast between a claimant and a defendant could not be greater. In the procedure the basic problem was that British law did not allow the granting of legal aid for the defendants ex officio in defamation cases. This caused an inequality of arms. It is worth noting that during the procedure discussed here the British legislator updated the relevant law (Access to Justice Act 1999) which sets up the exception [Sec. 8 (8)] that the State can take over the costs of legal aid on decision of the Lord Chancellor. Therefore, today in a similar case the defendants would have more chance in obtaining legal aid.

It is a matter of fact that at the time of the procedure the governing British law did not allow this, however the ECHR has the right to disregard such an unfavorable provision and it made its decision accordingly.

A British journalist, Oliver ${ }^{43}$ gave his article the title "David versus Goliath", in which he speculates what the motivation of the two tenacious opponents of McDonald's could have been to unremittingly fight for their truth for ten years. One reason, he thinks, was anger that the existing law denied legal aid in such cases. The other reason was the endeavor to open up the way for other campaigners and enable them to take action against big corporations with almost immeasurable excessive financial advantage without similar ordeals.

According to Hudson ${ }^{44}$ the most important result and consequence of the judgment of the ECHR for English law is that it opens the possibility to grant legal aid also in defamation cases. In his view this was envisaged by the Lord Chancellor when he was asked for the Government's response to the decision in the House of Lords. Thus, a serious step was taken in favor of the fortuneless defendants to be able to defend them efficiently in such cases.

A further effect of the judgment upon the English court practice is that in the future in defamation cases, in assessing the size of the award or damages having been extremely high value up to that time, also the financial situation of the defendant will be considered in case the defendant can suitably prove to be of limited means - says Hudson. ${ }^{45}$

The length of the procedure lasting for almost ten years and its costs indicate how high its own reputation, trademark and image is evaluated by the McDonald's holding, since the fee of lawyers alone was about 10 million $\mathrm{GBP}^{46}$ and there is no data what the cost of the private investigators' three-year work prior to that could have been.

\section{SUMMARY}

The purpose of the present paper was legal fact-finding without any special theoretic commentary. The result shows that trademark property only rarely meets human rights.

If the two areas of law: human rights and the law of trademarks meet after all, it can be considered to be an exception. Thus, such cases are unlikely to constitute a bar to the ordinary application of rules or practices of the trademark law of the States being parties to the Convention.

43 Oliver (2005)

44 Hudson (2005) 301.

45 Hudson (2005) 301.

46 Lillard (2005) 895. 


\section{LITERATURE}

Beiter, K. D., 'The Right to Property and the Protection of Interests in Intellectual Property' (2008) 6 International Review of Intellectual Property and Competition Law, 2008, 714-721.

Grabenwarter, Ch., European Convention on Human Rights (CH Beck 2014)

Grád, A., Weller, M., A strasbourgi emberi jogi bíráskodás kézikönyve [Manual of Human Rights Arbitration of Strasbourg] (4 edn, HVG Orac 2011)

Gyenge, A., Szerzői jogi korlátozások és a szerzői jog emberi jogi háttere [The System of Limitations and the Human Rights Background of Copyright] (HVG-ORAC 2010)

Helfer L. R., Austin G. W., Human Rights and Intellectual Property (CUP 2011)

Hudson, A., 'Free Speech and Equality of Arms' (2005) 3 European Human Rights Law Review, 301-309.

Karpenstein, U., Mayer, F. C., EMRK Konvention zum Schutz der Menschenrechte und Grundfreiheiten (CH Beck 2012)

Koltay, A., A szólásszabadság alapvonalai [Baselines of Freedom of Expression] (Századvég 2009)

Leach, Ph., Taking a Case to the European Court of Human Rights (3 edn, OUP 2011)

Lillard, M. C., 'McGoliath v David: The European Court of Human Rights Recent "Equality of Arms" Decision' (2005) 6 German Law Journal, 895-907.

Oliver, M., 'The McLibel case' (2005) 15.2. The Guardian

Polgári, E. et al., 'Alkotmányos és nemzetközi emberi jogi követelmények a rendes bíróságok gyakorlatában' in Z Fleck (ed), Bíróságok mérlegen [Courts on Scale], vol 2 (Budapest 2008), $75-184$.

Rahmatian, A., 'Trade Marks and Human Rights' in PLC Torremans (ed), Intellectual Property and Human Rights (Wolters Kluwer 2008)

Rainey, B., Wicks. E., Ovey, C., Jacobs, White \& Ovey: The European Convention on Human Rights (6th edn, OUP 2014)

Sajó, A., A szólásszabadság kézikönyve [Manual to the Freedom of Expression] (KJK-KERSZÖV 2005)

Sebastian, S., 'Geistiges Eigentum als europäisches Menschenrecht' (2013) 6 GRUR International, $524-534$.

Vida, S., ' (2014) 3 Iparjogvédelmi és Szerzői Jogi Szemle, 87-102. 